\title{
PROBLEMS AND WAYS OF INCREASING THE ENERGY EFFICIENCY OF THE SUGAR FACTORY
}

\author{
N. A. MIEDVIEDIEVA, Ph.D., Associate Professor, \\ ORCID: https://orcid.org/0000-0002-9475-0990 \\ V. YU. SUKHENKO, Ph.D., Doctor of Technical Sciences, Professor, \\ ORCID: https://orcid.org/0000-0002-8325-3331 \\ N. M. SLOBODYANYUK, Ph.D., Associate Professor, \\ ORCID: https://orcid.org/0000-0002-8325-3331 \\ National University of Life and Environmental Sciences of Ukraine \\ E-mail: medvedeva-natali@ukr.net; \\ vladsuhenko@nubip.edu.ua; slob2210@ukr.net
}

\begin{abstract}
Production of sugar and beet requires significant energy consumption Their rational use and the need to preserve the environment is caused not only by the cost of energy resources, but is one of the ways to increase competitiveness. The technology of sugar manufacture at "Novorozhitsky Sugar Plant» is considered, at each stage of technological operations the incoming resources, including material, are determined. The article presents the results of theoretical and practical analysis according to the data of the energy audit of a sugar plant. The results of monitoring the consumption and generation of energy resources for each species were analyzed. The diagnostic survey of the economy allows determining the areas of excessive consumption of energy resources and identifying potential energy conservation specialist. The measures and technical solutions to improve energy efficiency sugar factory are proposed. An economic assessment of the technical solution for the replacement of presses and determine the payback period has been carried out.

Keywords: energy audit, sugar production, energy saving, rational consumption, energy efficiency
\end{abstract}

\section{Introduction.}

Today, the energy policy of the developed countries of the world is focused on the awareness of the exhaustion of traditional fuel and energy resources. Consequently, the problem of energy supply, rational energy consumption and reduction of emissions to the environment requires concerted actions of state bodies, organizations and individuals. After the accession of Ukraine to the Energy Community Treaty, we are paying much attention to energy conservation, energy efficiency and renewable energy sources, and we strive to take a worthy place among the developed economies of the world.

Sugar industry is one of the main components of the entire agro-industrial complex. Beet sugar production is one of the most water-intensive industries in the agro-industrial complex, for example, one ton of sugar from beets needs to spend about $60 \mathrm{~m} 3$ of water, 
whereas in meat-packing plants per 1 ton of meat there is $6,9-8,9 \mathrm{~m} 3$ of waste water, 1-2 $\mathrm{m} 3$ of water is consumed per 1000 liters of processed milk. The production of sugar has a continuously streaming mechanized production with a high level of automation of the main processes. Over the past 10 years, the decrease in specific consumption of fuel equivalent has taken place only by $0.2 \%$ to the mass of beets (m.b.), because of the reduction of the cost of FER to the level of $4-5 \%$ of the conventional fuel to m.b. individual plants [1].

Worldwide practice shows that energy efficiency is achieved mainly due to organizational changes in the energy management system of an enterprise or city.

The main direction of increasing the competitiveness of sugar beet and sugar production is reducing the consumption of energy resources, sucrose losses and compliance with the current requirements of environmental legislation. For example, implementing a system of energy management allows to achieve significant energy savings for relatively small financial costs - at 3-5\% for 1 - 2 years.

In this regard, it is necessary to solve a number of agricultural and economic measures aimed at increasing the energy and economic efficiency of sugar beet production. However, it is necessary to have a clear idea of the possibilities of energy efficiency for the implementation of the strategic goal, to know the methodology of conducting the energy audit, its features and requirements. The first stage in the implementation of measures to increase energy efficiency is conducting energy audit of the enterprise.

\section{Literature review and problem statement.}

In accordance with the Energy Efficiency Directive 2012/27 / EC [2] (DEE), mandatory and regular energy audits of large enterprises and companies subject to privatization are introduced in Ukraine. The feature of the Directive is the lack of requirements to actual implementation of energy efficiency measures identified in the audit, in addition to companies and organizations that implement energy management system and environmental management are exempt from this requirement [3].

In the world energy sphere, based on current national standards, the practice of developing and improving international energy standards is implemented, while unifying the international standards of the ISO series.

International Standard for Power Management Systems DSTU ISO 50001:2014 [4] offers organizations a proven approach to developing an energy management plan addressing critical energy efficiency issues. This plan includes data on energy use, monitors, documentation, reporting, design and procurement practices, and other variables that affect the management of energy that can be measured and monitored.

The management and technical aspects of the standard of the ISO 50001 series are a peculiar structured and comprehensive organization guide for optimizing energy consumption and system management by this process. [5]. It should be noted that this standard requires "energy reviews" as an integral part of the energy management system to be developed, registered and stored.

When conducting an energy audit it is impossible to avoid the issue of the economic evaluation of organizational and technical measures to increase industrial energy efficiency, which are disclosed in the works $\mathrm{R}$. H. Coase [6]. Issues of energy saving and energy efficiency policy at the state level in his works were considered by V. Dzhedaul, T. Serdyuk, O. Prokopenko [7]. 
Today, experts in the industry [8, 9] and literary sources [10, 11], wellknown factors that cause over-consumption of fuel, and the role of each factor in energy conservation.

According to the results of the authors' studies [12], the main direction of the savings of FER in sugar-beet production is by reducing the heat (steam) costs of the process, in particular, by increasing the sugar recovery from the welded fillmass.

The main energy saving measures implemented at the most energy-efficient sugar factories of Ukraine are [13]:

- reduction of pumping of diffusion juice due to introduction of pulp pressing process and return of pressurized water to the diffusion process with the installation of pressed presses with a high degree of spin (22-32\% CP), improvement of the quality of beet chips and feed water;

- reduction of the amount of watered juice on the machine tool, replacement of obsolete filtering equipment on automated chamber filter presses.

One more direction of cost reduction for production of sugar and increase of energy efficiency of the enterprise is increase of durability and reliability of operation of equipment of sugar factories. So in materials [14] with high wear and corrosion resistance for increasing durability of parts of diffusion apparatus operating in aggressive technological environments of sugar beet production are given.

A number of energy saving measures (improvement of thermal insulation, use of heat of condensates, etc.) provide a reduction of the cost of steam for separate technological processes. But at the same time the amount of evaporated water in the evaporation unit should decrease as well. However, such measures create only the potential for saving pairs, but the effect of their introduction may be negative, that is, lead to an increase in the cost of the technological process. This leads to the fact that a significant proportion of the resulting energy saving effect is lost. Therefore, during the diagnostic audit it is expedient to determine the features of the plant's project, technology, equipment used, labor organization to evaluate the capabilities of this enterprise and identify priority measures for energy conservation.

The aim and objectives of the study. Research on the distribution of energy resources consumption at a sugar plant during the energy survey, the development of technical measures to improve its energy efficiency and their assessment in the implementation.

The main research material. During the energy audits of sugar factories, the following tasks are solved: analysis of the actual state and efficiency of energy use, identification of causes of losses or inefficient energy expenditures, their classification and evaluation; establishment of rational volumes of energy consumption in production processes and installations; establishment of optimal directions, means and volumes of use of primary and secondary energy resources; assessment of reserves for energy conservation - the potential of energy saving; the establishment of the possibility of improving the modes of technological and energy equipment; development or refinement of the norms of the cost of FER for the production of products, works, services (PRP); organization or improvement of energy accounting and control systems; recommendations for the installation of new equipment and improvement of technological processes. A generalized scheme for conducting energy surveys and audits is shown in Fig.1. 


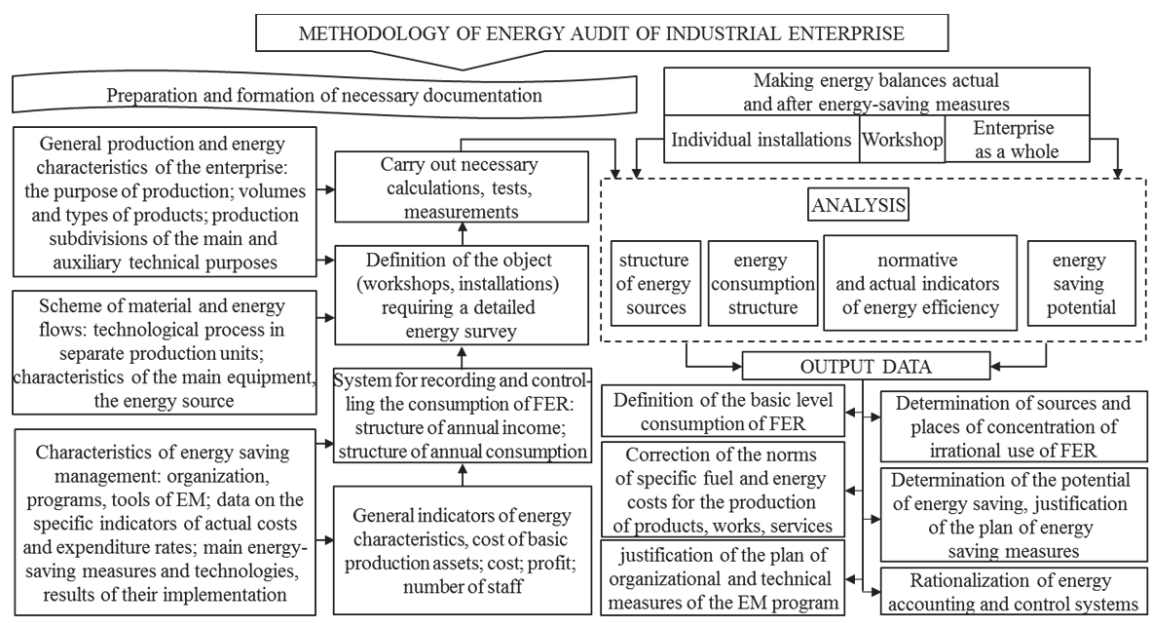

\section{Fig.1. Block diagram of energy surveys and audits}

The results of the energy survey of an industrial enterprise, in which the authors of the article in the energy audit group participated, are listed below.

In general, a modern sugar factory is a large enterprise with a developed infrastructure, which includes a technological line of sugar production, technological lines of additional enterprises (production of lime and carbonation gas, CHP). Technological lines of by-products (drying pulp, desugarization molasses), storage of sugar beet, sugar, molasses, pulp, water management (fresh water source, recycle systems, waste water treatment plants), automobile and railway tracks equipped with modern technological equipment using automation and computer equipment. Most sugar factories are being built along with a water source (rivers, ponds, wells, etc.) due to high consumption and water requirements.

The production of crystalline white sugar from sugar beets is based on successive basic technological operations and includes the following steps: preparation of sugar beets; obtaining diffusion juice; purification of diffusion juice; condensation of purified juice; juice evaporation; fillmass boiling; crystallization of sucrose; drying and packing of sugar. In addition, the auxiliary streams of lime milk and carbonate gas, wastewater treatment are used. The block diagram of sugar production from sugar beets is shown in Fig.2.

Despite the similar technological process of producing sugar, each plant in its production has its own differences in the production, use and consumption of energy resources. Let's consider the features of the energy economy at the investigated enterprise.

The main directions of using energy at a sugar plant are shown in the table 1 .

According to the table it can be seen that the electric power is supplied to the subscriber substation $(35 / 6 \mathrm{kV})$, from where along the outgoing $6 \mathrm{kV}$ lines the requested main divisions of the enterprise. Electricity from the network is used mainly in the non-production period (10500 $\mathrm{kWh} /$ day) and significantly less during the production period $(3330 \mathrm{kWh} /$ day).

During the production period, the CHP plant operates in a closed loop. 


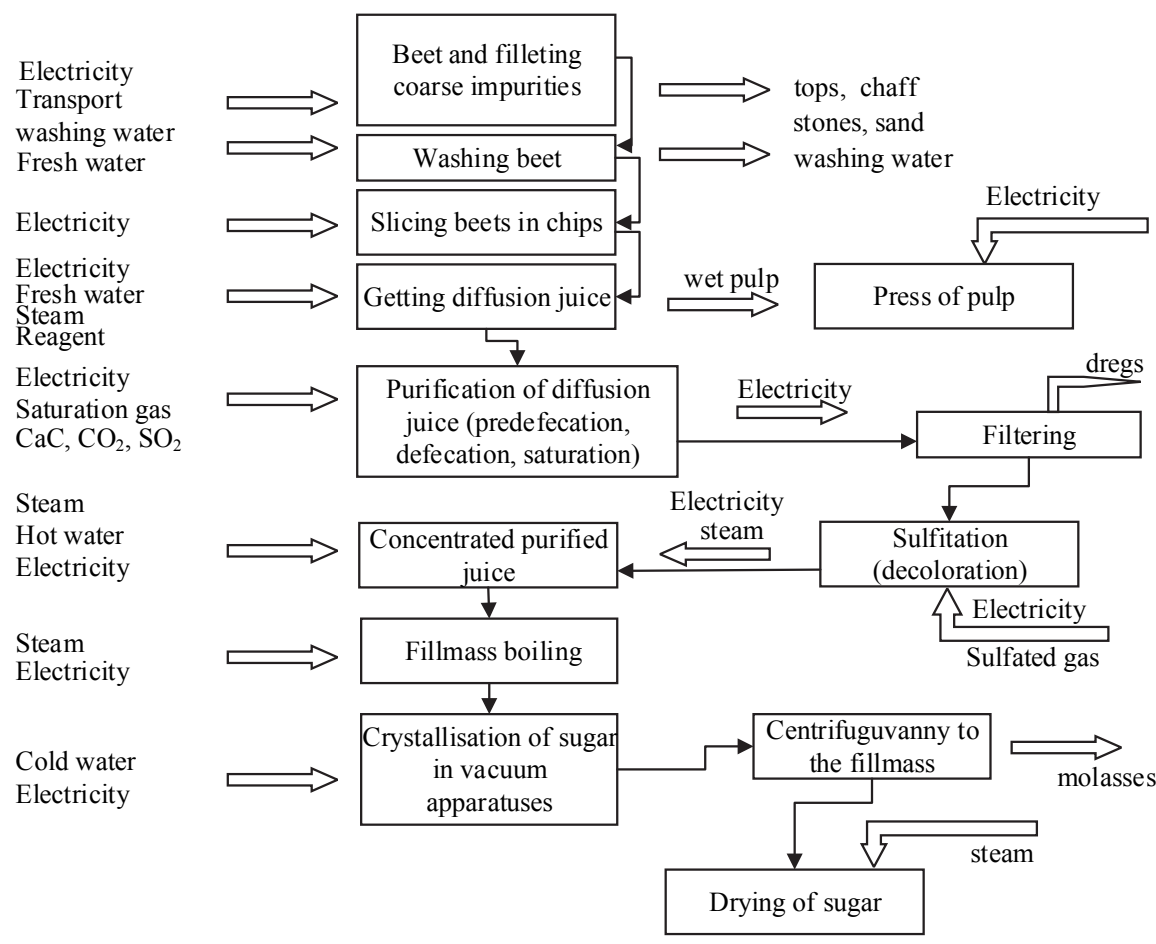

Fig. 2. Structural block diagram of sugar production

Part of steam produced in steam boilers is used in a steam turbine to generate electricity using a turbine generator. In addition to own needs, the generated electricity can be sold to the network.

Calculations for the consumed and generated in the network of electric energy are carried out on the testimony of commercial accounting systems installed at the boundary of the balance sheet.

During the energy survey of production and analysis of energy indicators, electricity consumption was determined and consumers were identified. Data on monthly electricity consumption are shown in table 2 , the balance of electricity consumption is shown in the figure. 3 .

As indicated in the table. 1, primary energy is natural gas, which account is made on the basis of commercial accounting data.
The main consumers of natural gas at the enterprise are steam boilers with a steam output of $75 \mathrm{t} / \mathrm{h}$ and $50 \mathrm{t} / \mathrm{h}$ ). The remainder of natural gas is consumed mainly for drying pulp in drying drums. Data on natural gas consumption are shown in Table 3, Figure 4 shows the balance of electricity consumption.

Reversible water at the plant is used in almost all technological processes and divided into two categories depending on its purpose. Water of the 1st category in the system of circulating water supply plant uses a heat conduction, and it is heated in the process of use (main condensers of process equipment, cooling equipment). Before re-use, it is precooled in a water-cooling tower.

Water II category in the circulating water supply system is used mainly in a hydrotransporter and a beet mixer. Be- 


\section{The main energy resources of the enterprise}

\begin{tabular}{|c|c|c|c|}
\hline № & $\begin{array}{l}\text { Primary energy } \\
\text { carrier }\end{array}$ & $\begin{array}{c}\text { Secondary energy } \\
\text { carrier }\end{array}$ & Directions of use \\
\hline 1 & Electricity & $\begin{array}{l}\text { Compressed air } \\
\text { Circulating water }\end{array}$ & $\begin{array}{l}\text { Drive of electric motors of technological } \\
\text { equipment. } \\
\text { The drive of smoke exhausters, fans and pumps. } \\
\text { Formation of compressed air. } \\
\text { Industrial lighting; } \\
\text { Office cabinets and office equipment. } \\
\text { Technological (pneumatic) and repair needs. } \\
\text { I category: } \\
\text { Beetroot } \\
\text { Carbonation gas washer } \\
\text { Dilution of filtration precipitate } \\
\text { dhe main evaporator condensers and vacuum } \\
\text { devices } \\
\text { Capacitor vacuum filters } \\
\text { Cooling equipment } \\
\text { Technological needs of CHP } \\
\text { IIcategory: } \\
\text { Hydrocracker } \\
\text { Beetroot }\end{array}$ \\
\hline 2 & Natural gas & $\begin{array}{l}- \\
\text { Saturated couples } \\
\text { Electricity }\end{array}$ & $\begin{array}{c}\text { Steam boilers } \\
\text { Crush drying drums } \\
\text { Technological use in aggregates Household and } \\
\text { domestic needs (heating, GVP) } \\
\text { See above }\end{array}$ \\
\hline 3 & Reversible water & - & $\begin{array}{l}\text { Previous evaporator condensers and vacuum } \\
\text { devices }\end{array}$ \\
\hline 4 & Drinking water & - & Cooling equipment \\
\hline
\end{tabular}

fore reuse, waste water is cleaned at the treatment facilities - radial settlers.

Drinking water extracted from own wells is used primarily for housekeeping needs. Consumption per year of drinking water is 16.76 thousand $\mathrm{m} 3$, and technical water 370,20 thousand cubic meters. $\mathrm{m}$. The balance of water use by the sugar plant is shown in Fig. 5.

\section{Monthly electricity consumption by the enterprise}

\begin{tabular}{|l|l|c|c|l|c|}
\hline № & Month & $\begin{array}{c}\text { Consumption of active energy } \\
\text { of the 1-st class, kWh }\end{array}$ & № & Month & $\begin{array}{c}\text { Consumption of active energy } \\
\text { of the 1-st class, } \mathrm{kWh}\end{array}$ \\
\hline 1 & January & 91079 & 7 & July & 143976 \\
\hline 2 & February & 88589 & 8 & August & 201543 \\
\hline 3 & March & 65538 & 9 & September & 237815 \\
\hline 4 & April & 67806 & 10 & October & 191699 \\
\hline 5 & May & 106331 & 11 & November & 83922 \\
\hline 6 & June & 141691 & 12 & December & 207919 \\
\hline \multicolumn{5}{|c|}{ YEAR 1627908} \\
\hline
\end{tabular}




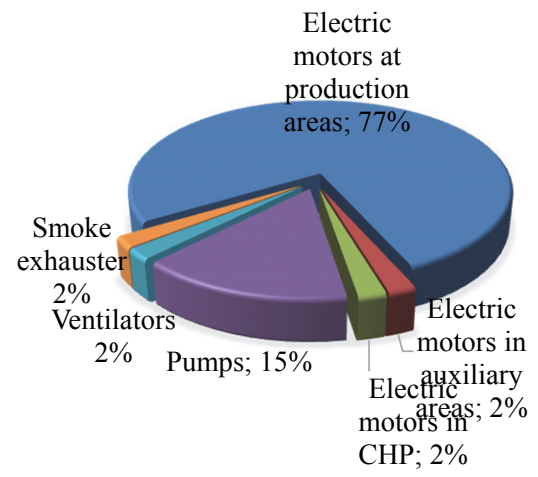

Fig. 3. Balance of electricity consumption of the researched sugar plant

Based on our research, we identified areas of elements of an enterprise with significant energy consumption and significant potential for energy savings. These energy elements include: steam boilers; evaporation stations; vacuum machines; press for money; centrifuges; pumps of water cycles; compressed compressed air.

According to the results of the analysis of the energy survey of the sugar plant, we determined that the two presses are not able to optimally handle the task of full squeeze pulp. Spent beet chips (pulp) remaining after extraction of sugar from her diffusion method is a cheap source of feed for cattle.This pulp comes from beet

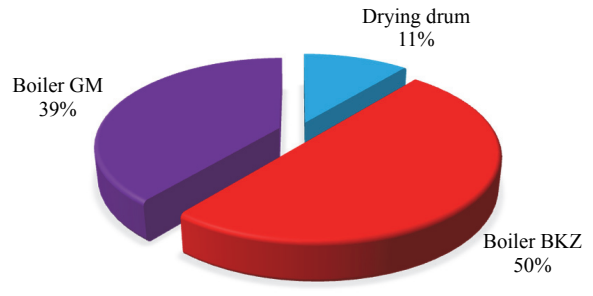

Fig. 4. Balance of natural gas consumption of the researched sugar plant

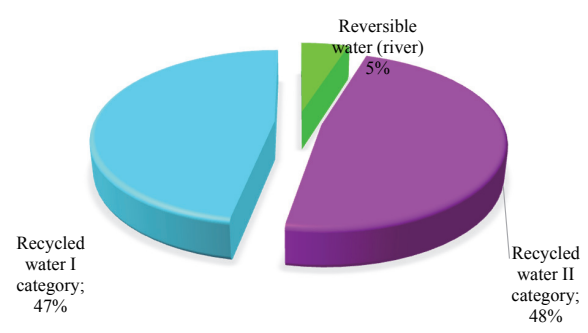

Fig. 5. Balance of water use by sugar plant

diffuser with a content of dry substances from 7 to $9 \%$ and, consequently, undergoes a drying process to reduce the water content in it and increase the content of solids to a level of $88 \ldots . .92 \%$.

The main disadvantage of drying pulp is the high consumption of fuel (natural gas) for this operation. Drying

\section{Monthly consumption of natural gas by a sugar factory}

\begin{tabular}{|l|l|c|c|c|c|}
\hline № & Month & $\begin{array}{c}\text { Consumption of natural } \\
\text { gas , m3 }\end{array}$ & № & Month & $\begin{array}{c}\text { Consumption of natural } \\
\text { gas , m3 }\end{array}$ \\
\hline 1 & January & 6222 & 7 & July & - \\
\hline 2 & February & 5141 & 8 & August & - \\
\hline 3 & March & 3809 & 9 & September & - \\
\hline 4 & April & - & 10 & October & 5789912 \\
\hline 5 & May & - & 11 & November & 6862217 \\
\hline 6 & June & - & 12 & December & 262318 \\
\hline \multicolumn{5}{|r|r|r|}{12929619} \\
\hline
\end{tabular}


of pulp without pressing is economically disadvantageous because it consumes an excessive amount of energy. To increase the economic feasibility of the drying process, mechanical pressing should be used. This operation allows most of the water contained in the pulp to be mechanically removed before the pulp arrives in the drying drums.

For this reason, the profitability of a sugar plant depends on the mechanical dehydration of pulp, whose effectiveness depends on both the performance of the equipment and the quality of wet pulp. All this plays a key role in controlling overall maintenance cost.

Mechanical dehydration of fresh pulp coming from diffusion devices, allows to reduce the consumption of natural gas in a dryer. The purpose of further calculations is to assess the economic benefits achieved through savings in maintenance cost (lower fuel consumption).

So, consider two options for the preparation of pulp to the process of drying it and determine the most economical.

By using press-old generation station after diffusion pulp enters the dryer with an average dry matter content of 22 $\%$ (option 1). The pulp after diffusion passes through a new dewatering station (Variant 2), consisting of two presses of the new generation of Babbini and fed into a dryer with dry matter content of about $28 \%$.

It was established that the productivity of a sugar plant is 6000 tons of beet / day, the length of the production period is 100 days / year., natural gas is used for drying.

According to formula Klassen, processing 6,000 tons of beets / day corresponds to a different number of pressed pulp in two cases that we examined:

Option 1 - The amount of pressed pulp per day is 1285 tons;
Option 2 - The amount of pressed pulp per day is 1000 tons.

An increase in the daily amount pulp-press waterare 285 tons of pressed pulp per day (transition from Option A to Option C), or $11,875 \mathrm{~kg}$ of pressed pulp water per hour, provided clock operation presses.

This calculation shows savings in terms of the amount of water that will not need to evaporate in the dryer to achieve the same content of dry matter after drying.

Approximately the same result is obtained by analytical balance of preserving the mass and dissolved substances in the dryer.

From the thermal balance of the dryer, we traditionally calculate the following average value of the energy required to evaporate $1 \mathrm{~kg}$ of water, which is equal to $\mathrm{Qtot}=750 \mathrm{kcal} / \mathrm{kg}$. The technical and economic indicators of the implementation of the energy saving solution for the replacement of pulp presses are given in Table 4.

The replacement of presses allows the use of pulp-press water in diffusion apparatuses and preserves a large amount of heat energy that is necessary for drying pulp. Mechanical pressing has such advantages:

- maximum removal of water contained in the pulp (about $80 \%$ );

- increase the amount of water for extraction (reducing the need for technical water);

- reduction of sugar losses in pulp, which is pressed;

- reduction of heat energy consumption for pulp drying process (reduction of natural gas consumption by drums);

- reducing the amount of pressed pulp improves the energy balance of extraction;

- improved storage of pressed pulp. 


\section{Technical and economic indicators of energy saving solutions}

\begin{tabular}{|l|l|l|l|l|}
\hline № & \multicolumn{1}{|c|}{ Indicator } & $\begin{array}{c}\text { Units of } \\
\text { measurements. }\end{array}$ & $\begin{array}{c}\text { Basic } \\
\text { value }\end{array}$ & $\begin{array}{c}\text { Value after } \\
\text { upgrade }\end{array}$ \\
\hline 1 & Reducing the need for evaporation of water & $\mathrm{kg}$ water / hour & - & 11875 \\
\hline 2 & $\begin{array}{l}\text { Thermal energy required for evaporation of 1 } \\
\text { kg of water }\end{array}$ & $\mathrm{kcal} / \mathrm{kg}$ of water & 750 & 750 \\
\hline 3 & Saving heat energy & $\mathrm{kcal} / \mathrm{h}$ & - & 8906250 \\
\hline 4 & Calorific contentof natural gas & $\mathrm{kcal} / \mathrm{m} 3$ & 8200 & 8200 \\
\hline 5 & Production lead time & day / year & 100 & 100 \\
\hline 6 & Reducing natural gas consumption & $\mathrm{m} 3 /$ season & - & 2606700 \\
\hline 7 & $\begin{array}{l}\text { Total costs for the implementation of } \\
\text { activities }\end{array}$ & $\mathrm{UAH}$ & - & 46000000 \\
\hline 8 & Energy saving effect ** & UAH / season & & 18600000 \\
\hline 9 & SPP (Simple period of return on investment) & seasons & - & 2,5 \\
\hline
\end{tabular}

\section{Conclusion.}

In order to increase the energy efficiency of the sugar plant, an energy audit was carried out that includes an inspection of the economy to identify areas of over consumption and evaluate technical solutions for energy efficiency. The main energy sources at the enterprise under consideration are electricity, natural gas, reversible water and drinking water. The survey results identified the largest consumers of the listed energy resources.

On the basis of energy consumption and the current state of the production capacity of the sugar plant, energy balances of energy consumption of the enterprise were constructed.

The technical solutions for improving energy efficiency are proposed, due to the replacement of pressing. Economically justified the decision to remove water from the wet pulp by mechanical means at the expense of pressing before drying heat. A simple return on investment is 2.5 years.

\section{Reference}

1. Levitskiy, Ya. G., Dmitruk, A. P., Chernyakhovskiy I. B., Schutskiy I. V., Krutybich, A. N. (2001).
Opyt Chortkovskogo sakharnogo zavoda po snizheniyu raskhoda topiva [Experience Chortkovskogo sugar factory to reduce the consumption of tops]. Sugar of Ukraine, 5, 19-20.

2. Directive 2012/27/EU of the European Parliament and of the Council of 25 October 2012 on energy efficiency.

3. Miedviedieva, N. A., Volynets, A. V., Cherevashko, D. I. (2018). Shliakhy pidvyshchennia enerhoefektyvnosti pidpryiemstv kharchovoi promyslovosti [Ways to improve the energy efficiency of food industry enterprises]. Scientific journal of NULES of Ukraine. Series: Bioresources and Nature Management, 10, 1-2, 124-128.

4. SSTC ISO 50001:2014 (2014). Enerhozberezhennia systemy enerhetychnoho menedzhmentu. Vymohy ta nastanova shchodo vykorystannia [Energy saving system of energy management. Requirements and usage guidelines].

5. Cherevashko, D. I., Volynets, A. V., Miedviedieva, N. A. (2018). Mekhanizm efektyvnoho vykorystannia enerhetychnykh resursiv [Mechanism for efficient use of energy resources]. Standardization, certification, quality, 1 (108), 58-68.

6. Coase, R. (1960). The problem of social costs. The Journal of Low and Economics. 
7. Prokopenko, O. V. ed. (2014). Ustoychivoerazvitiepredpriyatiya, regiona, obshchestva: innovatsionnyepodkhodykobespecheniyu [Sustainable development of the enterprise, region, society: innovative approaches to ensuring].Polsha: «Drukarnia i Studio Graficzne Omnidium», 474.

8. Filonenko, V. M. (2000). Enerhozberezhennia ta ekspluatatsiini faktory $v$ tsukrovomu zavodi [Energy saving and exploration factor in a gold factory]. Sugar of Ukraine, 2 , 17-19.

9. Fokin, V. M. (2006). Osnovy energosberezheniya i energoaudita [Basics of energy saving and energy audit]. Moscow, Russia: Mechanical Engineering, 256.

10. Knyazev, A. O. et al. (1994). Raskhody tepla i topiva na proizvodstvo sakhara: perspektivnye, proektnye, real'nye [Heat and fuel consumption for the production of sugar: promising, project, real]. Sugar of Ukraine, 1, 8-13.
11. Filonenko, V. M., Priadko, M. O. (2005). Enerhozberezhennia $v$ buriakotsukrovii haluzi. Realnyi stan ta perstpektyvy [Energy saving in buryakotsukroviy galuzi. The real camp of the perception]. Sugar of Ukraine, 5, 35-38.

12. Khrystynko, V. I., Shtanheiev, K. O. (2003). Napriamky enerhozberezhennia $v$ tsukrovii promyslovosti Ukrainy [Direct energy savings in Ukraine's industrial branches]. Sugar of Ukraine, 1, 17-19.

13. Shtanheiev, K. O., Khrystynko, V. I., Vasylenko, T. P., Vasylenko, S. M. (2014). Enerhoekonomichni faktory pidvyshchennia enerhoefektyvnosti tsukrovoi promyslovosti [Energy Factors Factors Energy Efficiency Objectives]. Sugar of Ukraine, 2 (98), 14-17.

14. Sukhenko, Yu., Miedviedieva, N., Sukhenko, V. (2017). Analysis and choice of coatings for increasing the durability of parts of diffusion units of sugar plants. Eastern-European Journal of Enterprise Technologies: Materials Science, 6/12(90), 27-34.

\section{Н. А. Мєдвєдєва, В. Ю. Сухенко, Н. М. СЛободянюк (2019). ПРОБЛЕМИ ТА ШЛЯ- ХИ ПІДВИЩЕННЯ ЕНЕРГОЕФЕКТИВНОСТІ ЦУКРОВОГО ЗАВОДУ. ТВарИНнИЦтвО та технології харчових продуктів, 10(1): 11-20.}

https://doi.org/

Анотація. Бурякове і цукрове виробництво потребує значного споживання енергетичних ресурсів. Раціональне їх використання та необхідність збереження навколишнього середовища обумовлено не тільки вартістю енергетичних ресурсів, а є одним із шляхів підвищення конкурентоспроможності. Розглянуто технологію виготовлення цукру на «Новооржицькому цукровому заводі», на кожному етапі технологічних операцій визначені вхідні ресурси, в тому числі і матеріальні. У статті наводяться результати теоретичного та практичного аналізу за даними енергетичного аудиту цукрового заводу. Проведено аналіз результатів моніторингу споживання і вироблення енергетичних ресурсів за кожним видом. Діагностичне обстеження господарства заводу дозволило визначити області надмірного споживання енергетичних ресурсів та визначити потенціал щодо енергозбереження. Запропоновано заходи й технічні рішення щодо підвищення енергоефективності цукрового заводу. Проведена економічна оцінка технічного рішення щодо заміни пресів і визначено термін його окупності.

Ключові слова: енергетичний аудит, виробництво иукру, енергозбереження, раціональне споживання, енергоефективність 